Between Art and Artifact 
THIS PAGE INTENTIONALLY LEFT BLANK 


\section{Between Art and Artifact}

ARCHAEOLOGICAL REPLICAS AND CULTURAL PRODUCTION IN OAXACA, MEXICO

Ronda L. Brulotte 
Copyright (C) 2012 by the University of Texas Press

All rights reserved

Printed in the United States of America

First edition, 2012

Requests for permission to reproduce material from this work should be sent to:

Permissions

University of Texas Press

P.O. Box 7819

Austin, TX $78713-7819$

www.utexas.edu/utpress/about/bpermission.html

(2) The paper used in this book meets the minimum requirements of ANSI/NISO Z39.48-1992 (R1997) (Permanence of Paper).

LIBRARY OF CONGRESS CATALOGING-IN-PUBLICATION DATA

Brulotte, Ronda L.

Between art and artifact : archaeological replicas and cultural production in Oaxaca, Mexico / Ronda L. Brulotte.

p. $\mathrm{cm}$.

Includes bibliographical references and index.

ISBN 978-0-292-73779-2 (cloth : alk. paper) — ISBN 978-0-292-73780-8 (e-book)

1. Indians of Mexico-Mexico-Oaxaca Valley-Material culture. 2. Indian wood-carving-Mexico-Oaxaca Valley. 3. Indian artMexico-Oaxaca Valley. 4. Cultural property-Mexico-Oaxaca Valley. 5. Art objects-Mexico-Oaxaca Valley-Reproduction.

6. Antiquities-Mexico-Oaxaca Valley-Reproduction. 7. Oaxaca Valley (Mexico)-Antiquities. I. Title.

F1219.1.011B $78 \quad 2012$

$972^{\prime} \cdot 74-\mathrm{dc} 23$ 
Para todos los artesanos de Arrazola TO ALL OF THE ARTISANS OF ARRAZOLA 
Copying is a bermeneutic task, in which the great contending paradigms of hermeneutics are at work, such as understanding, understanding better than the original, understanding differently, or even demonstrating the impossibility of understanding.

SÁNDOR RADNÓTI 